\title{
EVALUATION OF MOTHERS' KNOWLEDGE AND ATTITUDES OF ORAL REHYDRATION THERAPY IN CHILDHOOD DiARRHOEA
}

\author{
Muslim Olakunle Jamiu ${ }^{1 *}$, Giwa Abdulganiyu ${ }^{1}$, Okoro Nnaemeka Roland ${ }^{2}$ and Giwa \\ Halima Bukola ${ }^{1}$ \\ ${ }^{1}$ Department of Clinical Pharmacy and Pharmacy Practice, University of Ilorin, Ilorin, Nigeria \\ ${ }^{2}$ Department of Clinical Pharmacy and Pharmacy Administration, University of Maiduguri, Nigeria \\ *E-mail: jamolakunle@gmail.com \\ Tel.: +234 7039027492 .
}

Received: Jul 21, 2018 / Revised: Aug 06, 2018 / Accepted: Aug 07, 2018

The aim of present study was to assess the knowledge and attitudes of mothers in childhood management of diarrhoea with Oral Rehydration Therapy in Offa, Offa Local Government Area. A descriptive cross sectional study was conducted among mothers of child bearing age in Offa Local Government Area of Kwara State. Three hundred and fifty mothers participated in the study using systematic sampling technique. Data collection was by the use of Interviewer administered questionnaire. The data was analysed using SPSS version 20 . The most occurring age group was $26-30$ years. Seventy eight per cent $(\mathbf{7 8} \%)$ of mothers had good knowledge of diarrhoea disease and $55.5 \%$ were able to identify the causes of diarrhoea while about $85 \%$ had good knowledge of symptoms of diarrhoea. About $51 \%$ of the respondents used water closet in waste disposal and up to $11 \%$ used open defecation method. Respondents' method of sewage disposal influenced whether or not their children have experienced diarrhoea $(p=0.003)$. Mothers' level of education was affected by the knowledge of management of diarrhoea $(p=0.02)$. There was good knowledge of diarrhoea among mothers but majority had poor knowledge of ORS uses and preparation. Efforts should be made at the community level to improve appropriate use of $O R S$.

Key words: Diarrhoea, ORT, Mothers, Knowledge, Attitudes.

\section{INTRODUCTION}

Diarrheal diseases remain an important cause of mortality and morbidity among children, particularly in low- and middle-income countries (Thiam et al 2017). Diarrhea is a serious problem in many areas of the world and is especially lethal when superimposed on malnutrition. Diarrhea results in large losses of water and electrolytes, especially sodium and potassium, and frequently is complicated by severe systemic acidosis (Marie and Mark, 2005). Gastrointestinal (GI) infections are among the most common causes of morbidity and mortality around the world. Most are caused by viruses and some are caused by bacteria or other organisms. In underdeveloped and developing countries, acute gastroenteritis involving diarrhea is the leading cause of mortality in infants and children younger than 5 years of age (Marie and Mark, 2005). Diarrhea is a serious problem in many areas of the world and is especially lethal when superimposed on malnutrition. Diarrhea results in large losses of water and electrolytes, especially sodium and potassium, and frequently is complicated by severe systemic acidosis (UNICEF 2000).

Approximately four billion cases of diarrhoea occur each year and cause 2.2million deaths, mostly among children under the age of five (WHO 2000). This is equivalent to one child dying every $15 \mathrm{sec}$, or 20 jumbo jets crashing every day. These deaths represent approximately $15 \%$ of all child deaths under the age of five in developing countries (UNICEF 
2000). Although diarrhea kills about four million people in developing countries each year, it remains a problem in developed countries as well. In the United States, each child will have had 7-15 episodes of diarrhea by the age of 5 years, $9 \%$ of all hospitalizations of children less than 5 years old are associated with diarrhea, and 300-500 children die each year from this potentially preventable condition (Duggan et al 1992).

Oral rehydration therapy has now become the mainstay of the World Health Organization's efforts to decrease diarrhea morbidity and mortality, and Diarrheal Disease Control Programs have been established in more than 100 countries worldwide (Duggan et al 1992). Oral rehydration therapy adopted by the UNICEF and WHO in the late 1970s have been successful in helping manage diarrhea among children. It is estimated that in 1990s, more than 1 million deaths related to diarrhea may have been prevented each year, largely attributed to the promotion and use of these therapy. Today, however, there are indications that in some countries knowledge and use of appropriate home therapies to successfully manage diarrhea including ORT may be declining (WHO/UNICEF 2004).

Appropriate healthcare-seeking behavior could prevent a significant number of child deaths and complications due to ill health. Improving mothers' care-seeking behavior could also contribute in reducing a large number of child morbidity and mortality in developing countries (Webair and Bin-Gouth, 2013). Between 1990 and 2000, diarrhea-related deaths decline by half thereby achieving World Summit Goal. While the cause-specific mortality is difficult to measure, it is estimated that more than one million child deaths per year have been prevented.

The significance of the study was to assess the knowledge and attitudes of mothers on home management of childhood diarrhea. Childs' care primarily falls in mothers' hand and their ability in providing appropriate care for their child could reduce the attendant morbidity and mortality from childhood illnesses.

\section{METHODS}

\section{Setting}

The study was carried out in Offa, Kwara state, Nigeria. It is located 8.15 latitude and 4.72 longitudes and it is situated at elevation 419 meters above sea level and the administrative headquarters of Offa Local Government Area. Offa is centrally located in the midst and middle of many neighboring towns like Erin Ile in the south, Ijagbo in the north, Igosun and Ipee in the east and Ilemona, Irra, Ikotun and Ojoku in the west. Other towns surrounding Offa are Igosun and Igbo Idun. Offa has a population of 90,000 inhabitants. It operates on the WAT time zone, which means that it follows the same time zone as Ilorin, the Kwara State capital. The area occupation is mainly farming with sizable number of government employee, traders and artisans. The area has one secondary health institution a host of privately owned health facilities.

\section{Study population}

Mothers of under-five children resident in the LGA were included in the study. Households without at least one under-five child in the study areas were excluded.

\section{Study design}

This was a descriptive cross sectional study.

\section{Sampling technique}

Ten out of the 12 political wards in Offa LGA were selected using simple random sampling by simple balloting. Twenty households that met the inclusion criteria in each of the selected district were selected using systematic sampling technique. Households were sampled at interval of three household until a total of 20 households meeting the inclusion criteria was sampled. Only one member of the household meeting the inclusion criteria was sampled. The index house was determined using Grid method in which a bottle was spun in the centre of the district. The direction of the bottle after been spun determined the starting point of the sampling.

\section{Data collection and analysis}

Interviewer administered questionnaire was used to collect data. The data from questionnaire was sorted out and analyzed using SPSS version 17 results were presented in form of frequency tables and p-values < 0.05 were considered significant.

\section{RESULTS AND DISCUSSION}

A total of 350 mothers of under fives were sampled using Fisher's formula. 220 (62.8\%) of respondents were Muslims while 130 (37.1\%) were Christians. Majority of the respondents had tertiary education 203 (58\%), followed by those 
with secondary education $117.3(33.5 \%)$, and primary education 18 (5\%). Those that had no formal education were 12 (3.5\%).

Among the 350 respondents, 208 (59.5\%) got their source of water supply from tap, 61 $(17.5 \%)$ from wells and 80 (23.0\%) from boreholes. Respondents' method of sewage disposal included use of water closet 180 (51.4\%), use of pit latrine 132 (37.7\%) and open defecation 38 (10.9\%). Table 1 shows the age distribution of respondents.

Table 1. Age distribution of the respondents

\begin{tabular}{|c|c|}
\hline Age (years) & Frequency (\%) \\
\hline $18-25$ & $62(17.7)$ \\
\hline $26-30$ & $120(34.3)$ \\
\hline $31-35$ & $69(19.7)$ \\
\hline $36-40$ & $48(13.7)$ \\
\hline $41-45$ & $35(10.0)$ \\
\hline $46-50$ & $16(4.6)$ \\
\hline Total & $350(100)$ \\
\hline
\end{tabular}

The youngest respondent was 21 years of age while the oldest was 50 years of age. The age range therefore was 29 . All 350 respondents that participated in the survey claimed they were aware of diarrhea and their child or children had experienced one or more episodes in their childhood. Table 2 shows the respondents knowledge of the characteristics of diarrhea. When asked about their sources of information on their awareness, 108 (30.9\%) of them said it was through the mass media, 129 (36.9\%) through the hospital, 10 (2.9\%) through friends, $47(13.4 \%)$ through pharmacists and $55(15.7 \%)$ through relatives while only one respondent $(0.29 \%)$ indicated no response.

Table 2. Respondents' knowledge of the characteristics of diarrhea

\begin{tabular}{|c|c|}
\hline Mothers' knowledge of diarrhea & $\begin{array}{c}\text { Frequency } \\
\text { (\%) }\end{array}$ \\
\hline $\begin{array}{c}\text { Diarrhea as a disease characterized } \\
\text { by frequent watery stool for more } \\
\text { number of times than normal }\end{array}$ & $220(62.9)$ \\
\hline $\begin{array}{c}\text { Diarrhea is a disease that affect only } \\
\text { the children }\end{array}$ & $70(20.0)$ \\
\hline $\begin{array}{c}\text { Diarrhea results from careless } \\
\text { eating habit }\end{array}$ & $10(2.9)$ \\
\hline $\begin{array}{c}\text { Disease that can affect the child } \\
\text { development }\end{array}$ & $14(4.3)$ \\
\hline $\begin{array}{c}\text { Diarrhea is a disease without a } \\
\text { cause }\end{array}$ & $26(7.4)$ \\
\hline $\begin{array}{c}\text { Disease that results in loss of water } \\
\text { from the body }\end{array}$ & $10(2.9)$ \\
\hline
\end{tabular}

Out of 350 respondents, 228 (65.1\%) of them said increase fluid and food intake in a child with diarrhea is important, $80(22.9 \%)$ said it is not and $42(12.0 \%)$ were indecisive.

Table 3, 4 and $\mathbf{5}$ show the respondents' knowledge on the cause of diarrhea, symptoms of diarrhea and ways of preventing diarrhea respectively.

Table 3. Knowledge of mothers on the causes of diarrhea

\begin{tabular}{|c|c|}
\hline Causes of diarrhea & Frequency (\%) \\
\hline $\begin{array}{c}\text { Contaminated food and } \\
\text { drinks }\end{array}$ & $170(48.6)$ \\
\hline Sugar and sugary foods & $30(8.6)$ \\
\hline Milk and milk products & $21(6.0)$ \\
\hline Heat & $35(10)$ \\
\hline $\begin{array}{c}\text { Uncooked or poorly cooked } \\
\text { foods }\end{array}$ & $21(6.0)$ \\
\hline Unhygienic environment & $5(1.4)$ \\
\hline Poor mothers caring attitude & $12(3.4)$ \\
\hline Constipation & $5(1.4)$ \\
\hline Child's teething period & $22(6.3)$ \\
\hline Worm infestation & $5(1.4)$ \\
\hline Unknown cause & $25(7.2)$ \\
\hline
\end{tabular}

Substances used by mothers for their child during diarrhea episode include Antibiotics 26 $(17.2 \%)$, packet ORS 50 (33.1\%), Herbal medicine $4(2.6 \%)$, salt and sugar solution 33 $(21.9 \%)$ and general self-medication to stop the stooling 47 (31.1\%). Three (2\%) said they use nothing to stop or reduce the episode of diarrhea. Responding mothers were able to mention some of symptoms experienced by children during diarrhea episode (Table 4).

Table 4. Mothers' knowledge of most common symptoms of diarrhea

\begin{tabular}{|c|c|}
\hline $\begin{array}{c}\text { Mothers' knowledge symptoms } \\
\text { of diarrhea }\end{array}$ & $\begin{array}{c}\text { Frequency } \\
\text { (\%) }\end{array}$ \\
\hline $\begin{array}{c}\text { Frequent loose stool more } \\
\text { frequently than normal }\end{array}$ & $200(57.1)$ \\
\hline Vomiting & $52(14.9)$ \\
\hline General weakness in child & $20(5.7)$ \\
\hline Loss of appetite & $9(2.6)$ \\
\hline Paleness & $13(3.7)$ \\
\hline $\begin{array}{c}\text { Presence of mucus/blood in the } \\
\text { stool }\end{array}$ & $15(4.3)$ \\
\hline High body temperature & $41(11.7)$ \\
\hline
\end{tabular}

Symptoms of diarrhea respondents' believed should necessitate treatment were passage of 
blood/mucoid stool (102; 29.1\%), fever (53; $15.0 \%)$, vomiting $(74 ; 21.0 \%)$ and presence of signs of dehydration $(155 ; 44.5 \%)$. On the knowledge of preparation of ORS, One hundred and ninety two of this claimed they knew how to prepare the ORS sachet, out of this, 220 corresponding to $62.3 \%$ of them gave a correct response as to the preparation of ORS (that is, one ORS sachet + one liter of boiled and cooled water while $125 \quad(35.7 \%)$ gave incorrect responses while the rest $5 \%$ gave no response. Their knowledge sources include Doctor (73; 20.8\%), Pharmacist $(92 ; 26.3 \%)$, Nurses (70; $20.0 \%)$, Neighbors' (5; 1.4\%), Friends (9; 2.6\%), Mass media (4; 1.1\%) and reading of the instruction on the sachet $(4 ; 1.1 \%)$.

On the assessment of knowledge of preparation of home-made salt and sugar solution (SSS) by the respondents, Majority (80\%) said administration of homemade ORS should be with cup and spoon, $12 \%$ believes feeding bottle is the best while $8 \%$ did not give any response.

On restriction of food during diarrhea, $64.3 \%$ of mothers used to continue usual feeding and increased fluid while $36.7 \%$ believed some food should be restricted. Majority of those that believed food should be restricted were based on personal views while some claimed they had their information from nurses. Table 6 shows summary of the statistical analysis done on relationship of some variables on others.

Table 5. Mothers' knowledge of methods of preventing diarrhea in children

\begin{tabular}{|c|c|}
\hline Methods of diarrhea prevention & $\begin{array}{c}\text { Frequency } \\
\text { (\%) }\end{array}$ \\
\hline $\begin{array}{c}\text { Good mother child and } \\
\text { environmental hygiene }\end{array}$ & $155(44.3)$ \\
\hline Use of clean and treated water & $111(31.7)$ \\
\hline $\begin{array}{c}\text { Reduction of sugar and sugary food } \\
\text { intake }\end{array}$ & $30(8.6)$ \\
\hline Prompt treatment of infection & $25(7.1)$ \\
\hline $\begin{array}{c}\text { Eating properly cooked food and } \\
\text { avoidance of contaminated foods } \\
\text { and drinks }\end{array}$ & $10(2.9)$ \\
\hline Good child health care system & $19(5.4)$ \\
\hline
\end{tabular}

\section{DISCUSSION}

The respondent's age range cut across the childbearing age range for a woman which is from 15 to 44 years (Bopp and Seifer, 2008). In general, the age distribution of respondents gives a good representation of the reproductive age range for women in the locality. All forms of educational status were represented in this study; ranging from those who had no form of formal education to those who had tertiary education.

Table 6. Association between various factors influencing mothers' knowledge of diarrhea and it's management

\begin{tabular}{|c|c|c|}
\hline Test & Association & p-value \\
\hline 1 & $\begin{array}{c}\text { Mothers' level of education and } \\
\text { knowledge of management of } \\
\text { diarrhea }\end{array}$ & 0.002 \\
\hline 2 & $\begin{array}{c}\text { Mothers' level of education and } \\
\text { of food restriction in active } \\
\text { episode of diarrhea }\end{array}$ & 0.06 \\
\hline 3 & $\begin{array}{c}\text { Method of sewage disposal and } \\
\text { possibility of diarrhea disease }\end{array}$ & 0.003 \\
\hline 4 & $\begin{array}{c}\text { Knowledge of importance of } \\
\text { ORT and ability to correctly } \\
\text { prepare ORS }\end{array}$ & 0.052 \\
\hline
\end{tabular}

The respondents' sources of water supply generally indicate that most of the respondents had good source of water supply although less than a quarter of them get their water from borehole source. The quality of public supply of water these days may not be ascertained as ascertained as some tap water supplies has been reported of contamination due to improper treatment and leakage of service pipes, (Holisko et al 2013) incidentally, supply through the public tap water accounted for more than half of the sources. Although higher percentage of residents $(51.4 \%)$ used water cosset system of waste disposal but this is quite far lower than a study carried out in in Ilorin with up to $80 \%$ use of water closet method of sewage disposal (Jamiu et al 2012). This result could not be far from the fact that Ilorin is more urban in settlement and an administrative capital of the state. This accounts for $80 \%$ of total of 350 respondents. Open defecation was the least accounting for $3 \%$ while pit latrine method was $16 \%$. The high use of water closet could because Ilorin town is an urban area depicting that majority of houses being modern in nature, have good sewage disposal method.

A good knowledge of diarrhea was observed among the respondents as he results obtained from the respondents as more than two third of them were able to define what diarrhea was although few of them believed that it should contain mucus or blood before it could be dangerous for the child. The poor attitude of people in seeking medical attention for their ailment may worsen child condition as a child relies on mother's response to achieve his or her 
medical attention (Abdulraheem and Parakoyi, 2009). The result obtained here is similar to that obtained in a similar study carried out in Ajasse Ipo area of Kwara state where $95.5 \%$ of respondents were able to give correct definition of diarrhea (Adeyemi, 2008).

A good awareness of the mothers to identify causes of diarrhea as obtained in this study could be important in prevention of diarrhea episode in children. Identification of infectious organisms one of the causes of diarrhea was similar to a study carried out in Haiti; Dominican Republic where water, food and microbes were identified as the major causes of diarrhea (Kirkpatrick and Cobb, 1990). Identification of teething condition as one of the causes of diarrhea has been a wrong notion among nursing mothers in our society. In this study only $6.3 \%$ of the respondents agreed to this as against up to $71 \%$ obtained from a study in Enugu in Nigeria (Ene-Obong et al 2000). This assumption is also related to cultural issues among the Bangladeshi that diarrhea in children during teething may be regarded as normal (Larry, 2007)

The knowledge of mothers was also assessed on the use and preparation of ORS/SSS. Most mothers knowledge of use and function ORT in replacing lost fluid and electrolytes. ORS has been found to be very useful in reducing morbidity as a result of diarrhea, therefore the high awareness among mother will aid in taking the right step in the treatment of childhood diarrhea at home. However, when these mothers were asked on the preparation of ORS, only $62.3 \%$ of mothers were able to give correct responses. Their knowledge concerning this is quite low as it is below average despite the fact that their sources of information were more from the right sources: Pharmacists, Doctors and Nurses. Education of mothers is required in other to bring all of them to the knowledge of correct preparation of the item in order to exert its intended function. This value is also lower than value obtained from similar study in Ajasse Ipo, Kwara state (Adeyemi, 2008); two markets in Ibadan (Omonkhodion et al 1998) and Enugu urban (Ene-Obong et al 2000) where 97.5\%, $80 \%$ and $77 \%$ of respondents were able to prepare it correctly respectively; but higher when compared to a study carried out in Dharan, Nepal, where only $36.3 \%$ of the respondents knew oral rehydration fluid but only $6.1 \%$ knew complete procedure for its preparation (Chaudhary et al 2014).
Similar result as with preparation of ORS was obtained in this study when the respondents were asked on the preparation of homemade ORS-Salt Sugar Solution(SSS) as only $40 \%$ of the were able to give correct method of preparing home-made SSS. Though this result is more impressive than that obtained in Ikara L.G.A in Kaduna where only $14 \%$ of mothers could prepare the mixture correctly, the figure can still be considered as relatively low (Yakubu, 2012) The mothers' knowledge on SSS is very important when it comes to home treatment of diarrhea because the components could be more accessible and life-saving in emergency episode of diarrhea particularly in this semi urban community. Mothers needed to more educated and better informed on this.

Restriction of some groups of food was advocated by majority of the respondents in order to control the progression of diarrhea. According to another study conducted in Nigeria, foods were implicated in diarrhea causation if they were considered contaminated, excessively sweet or having the ability to dirty the stomach. Beans was noted for dirty stomach while sugary foods and overripe fruits caused were viewed as diarrhea causing foods (Uchendu et al 2011). The result obtained here was also in line with that obtained in the study conducted in Ajasse Ipo (Adeyemi, 2008). Ajasse Ipo is a neighboring community which is about $15 \mathrm{~km}$ to Offa. The approach of withholding food in diarrhea condition had previously been the routine procedure among care givers (Ashkanani and AlSane, 2013).

The significant relationship between educational level of the respondents is in tune with the expected trend. Higher level of education improve the understanding of care giver in disease management. This effect is similar to a study carried out in Morang community in Nepal where level of education was found to influence mothers' knowledge of managing diarrhea in children (Strina et al 2015).

Education is a vital tool in providing information. Contrarily, their level of education has no influence on knowledge of restriction of food in children with diarrhea. Although the idea of food restriction is an age long assumption, the scientific position is continued.

Also, there was association between respondents' method of sewage disposal and whether or not respondents' children have experienced diarrhea. Diarrhea experience was 
more among those who defecate in open environment. It is quite very possible because of the possibility of defecation having contact with mouth particularly among the toddlers. A similar result has been reported from a study conducted in Salvador, Brazil where poor defecation method has been found to influence the prevalence of diarrhea in children (Ashkanani and Al-Sane, 2013). Hence, the better sewage disposal system the less the incidence of diarrhea in children because better system can reduce direct contact between the sewage and the child.

Although, majority believed that ORS is a necessary in the management of childhood diarrhea their knowledge has no significant impact in their ability to correctly prepare the rehydration salts. This was evident as majority of them could not state correct procedure of preparing it. It follows that despite their frequent use of oral rehydration salt for diarrhea management in their children, inappropriate method of preparation might affect the effectiveness of the medicine (Uchendu et al 2011, Blum et al 2011). Although there are varied perception about the causes and management of diarrhea in Nigeria, (Ebelechukwu, 2002) adequate education and information of intervention with ORT is necessary from health care practitioners especially the pharmacists who are at the dispensing end to guide the care giver in the appropriate use of medicine especially in this life saving medicine called Oral Rehydration Salts.

\section{CONCLUSION}

The mothers had a good knowledge of diarrhea but poor knowledge of Oral Rehydration Therapy. Concerted efforts are necessary in order to improve their knowledge in both the disease condition and its management to reduce the morbidity and mortality associated with childhood diarrhea.

\section{REFERENCES}

Abdulraheem IS, Parakoyi DB. Factors affecting mothers' healthcare-seeking behavior for childhood diseases in a rural Nigeria setting. Early Child Dev. Care 2009;179(5): 671-83. [DOI: 10.1080/03004430701500885]

Adeyemi A. Knowledge, Attitude and Practice of mothers of under-five children on Home Management of Acute Diarrhea in Ajasse-Ipo Community, Kwara, Nigeria. A dissertation submitted to the Department of Epidemiology and Community Health, University of Ilorin, Nigeria, 2008.

Ashkanani F, Al-Sane M. Knowledge, attitudes and practices of caregivers in relation to oral health of preschool children. Med. Princ. Pract. 2013;22:167-72.

Blum LS, Prisca A. Oria PA, Olson C K, Breiman RF, Ram PK. Examining the use of oral rehydration salts and other oral rehydration therapy for childhood diarrhea in Kenya. Am. J. Trop. Med. Hyg. 2011;85(6):1126-33.

Bopp BL, Seifer DB. Glob. Libr. Women's Med. 2008. [DOI: 10.3843/GLOWM.10341]

Chaudhary P, Basu S, Dzeyie KA, Gulla S, Khade S, Patel A, Phukan D, Dikid Tkumar A, Shrivastava A. Illness in children under five years of age: a cross sectional study in an urban slum of Delhi, India. Indian J. Prev. Social Med. 2014;46(3):13-21.

Duggan C, Santosham M, Glass RI. The management of acute diarrhea in children: oral rehydration, maintenance, and nutritional therapy. Centers for disease control and prevention. MMWR Recomm. Rep. 1992;41(RR-16):1-20.

Ebelechukwu FU. Etiological Perceptions of childhood diarrhea among mothers of South East Nigeria. Nig. Med. rac. J. 2002;41:56-9.

Ene-Obong HN, Iroegbu CU, Uwaegbute AC. Perceived causes and management of Diarrhea in young children by market women in Enugu State, Nigeria. J. Health Popul. Nutr. 2000;18(2):97-102.

Holisko S, Speed D, Vodden K, Sarkar A. Developing a community-based monitoring program for drinking water supplies in the Indian Bay Watershed: A baseline study of surface water quality, contamination sources and resident practices and perceptions. The Harris Centre - RBC Water Research and Outreach Fund 2013:1-80.

Jamiu MO, Odili VU, Abu-Saeed K, Abu-Saeed MB. Assessment of mothers' knowledge of home management of childhood diarrhea in a Nigeria setting. Int. J. Pharm. Res Bio-sci. 2012;1(4):168-84.

Kirkpatrick SM, Cobb AK. Health beliefs related to diarrhea in Haitian children: building transcultural nursing knowledge. J. Transcult. Nurs. 1990;1(2):2-12.

Larry G. Acute Diarrhea and Oral Rehydration. Kliegman R, Behrman R, Jenson H, Stanton B. (eds.). Nelson Textbook of Pediatrics, 18th Edition, Saunders: Philadelphia, USA, 2007.

Marie AC, Mark WJ. Evaluation of the Gastrointestinal Tract. Pharmacotherapy Handbook, 6th Edition. Wells BG, DiPiro, JT, Schwinghammer T, Hamilton C. (eds.). McGraw-Hill Medical Publishing Division: New York, USA, 2005; 605-760.

Mukhtar A, Mohamed-Izham MI, Pathiyil RS. A survey of mothers' knowledge about childhood diarrhoea and its management among a marginalized community of Morang, Nepal. Australas Med. J. 2011;4(9):474-9.

Omonkhodion FO, Oyemade A, Sridhar MK, Olaseha IO, Olawuyi JF. Diarrhea in children of Nigeria market women: prevalence, knowledge of causes and management. J. Diarrhoeal Dis. Res. 1998;16(3):194200.

Strina A, Cairncross S, Barreto ML, Prado MS. Childhood diarrhea and observed hygiene behavior in Salvador, Brazil. Am. J. Epidemiol. 2015;157(11):1032-8.

Thiam S, Diène AN, Fuhrimann S, Mirko S. Winkler MS, Sy I, Ndione JA, Schindler C, Vounatsou P, Utzinger J, Faye O, Cissé G. Prevalence of diarrhoea and risk factors among children under five years old in Mbour, Senegal: a crosssectional study. Infect. Dis. Poverty 2017;6(1):109. [DOI: 10.1186/s40249-017-0323-1]

Uchendu UO, Emodi IJ, Ikefuna AN. Pre-hospital management of diarrhoea among caregivers presenting at a tertiary health institution: implications for practice and health education. Afr. Health Sci. 2011;11(1):41-7. 
United Nations Children's Fund (UNICEF) End Decade Databases. World Summit for Children on Diarrheal disease. Review of decade progress 2000.

Webair HH, Bin-Gouth AS. Factors affecting health seeking behavior for common childhood illnesses in Yemen Patient Prefer. Adherence 2013;7:1129-38. [DOI: 10.214 7/PPA.S51124]
World Health Organization (WHO). Global water supply and sanitation assessment 2000 report. Health hazards of poor water supply and sanitation. WHO publication 2000 .

WHO/UNICEF joint statement. Clinical Management of Acute Diarrhea. Nov 2004

Yakubu AM. Child Health Care in Nigeria: Historical background. Nig. J. Paediatr. 2012;39(1):1-6.

$* * * * *$ 